\title{
A Qualitative Study of the Initiation and Continuation of Preschool Inclusion Programs
}

MEGAN L. PURCELL

Eastern Kentucky University

\section{EVA HORN}

SUSAN PALMER

University of Kansas

ABSTRACT: Initiation and continuation of preschool inclusion is a challenging task. Through interviews and focus groups of school district and special education personnel, researchers in this study examined how 5 programs in 1 Midwestern state provided such services. The investigation used a multiple-case study methodology to examine how these programs initiated and sustained inclusive services. Especially important to these programs were factors such as having a shared vision, utilizing key personnel, and developing a structure within which the program could work.

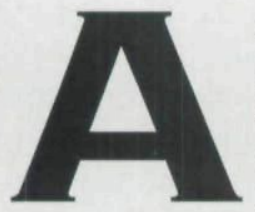

number of researchers have reported positive outcomes of inclusion for young children with disabilities (Buysse \& Bailey, 1993; Lamorey \& Bricker, 1993; Odom, Wolery, Lieber, Sandall, Hanson, Beckman et al., 1999). Others have noted that an inclusive model for early childhood education does not appear to produce any negative developmental or social effects for any of the children involved in these programs (Guralnick, 2001). Participation in such a program can have a beneficial impact on children both with and without disabilities, resulting in positive gains such as increased and more meaningful social interaction (Guralnick, 2001; Leyser \& Kirk, 2004; Stahmer \& Carter, 2005).
The 1997 and 2004 amendments to the Individuals With Disabilities Education Act support previous legislation regarding the inclusion of children with disabilities in educational environments with children without disabilities (IDEA 1997; 2004). Further, a student's individualized education program (IEP) must include provisions for students to be involved and progress in the general curriculum (20 U.S.C. $\$ 1414$ [A] [iii] [II]), which has been represented in education with the phrase "access to the general education curriculum” (Nolet \& McLaughlin, 2000). Inclusion is but one aspect of accessing the general education curriculum for students with disabilities. Rather than merely being concerned with the place where an instructional strategy or curriculum is used, inclusion involves young 
children "belonging, being valued, and having choices" (Horn, Thompson, Palmer, Jenson, \& Turbiville, 2004, p. 207). Although accessing the general education curriculum involves more than inclusion, being in the same location with the same or similar programming as children without disabilities is one meaningful way to ensure that students with disabilities are receiving some of the same instruction and interaction with typical peers - even if materials must be adapted or the curriculum altered to meet individual needs of young children with disabilities.

Although many local education agencies (LEAs) might not provide educational settings for preschool-aged children who are developing typically, they often look to collaborate with organizations and funding sources in the community when considering inclusive options for children with disabilities (Buysse, Wesley, Bryant, \& Gardner, 1999; File \& Kontos, 1992; Odom, Parrish, \& Hikido, 2001). Such collaboration often leads to a variety of programmatic forms, sometimes resulting in different programs within a single LEA (Odom, Wolery et al., 1999). In a study of 16 programs, Odom, Wolery and colleagues (1999) identified a two-dimensional model for describing how inclusion for preschool children with disabilities was implemented. These two dimensions are organizational context and individualized service of the program. Organizational context is the classroom model in which inclusion is supported (e.g., Head Start or public-school programs), and individualized services include specialized programs such as special education and related services.

When studying early childhood special education, particularly the inclusive models of service, a number of factors can be examined, including the impact of inclusion and access to the general curriculum on children, legislative support for the model of inclusion, and the organizational contexts and individualized service models in which inclusion is delivered. A particularly important element in the study of inclusion is the role of innovative change in the development of these programs. Innovative change in education has been analyzed and documented by researchers in general education and early childhood education in particular (Fullan, 2001; Mayrowetz \& Weinstein, 1999; Peck, Furman, \&
Helmstetter, 1993; Wesley \& Buysse, 1996). Fullan, for example, described three phases for innovative change in education: (1) initiation, (2) implementation, and (3) institutionalization. As early childhood special education programs continue to grow and change, LEAs can employ factors similar to those used by Fullan. For instance, advocacy, clarity, and agreement on the meaning and need for change; development of new policies; and access to funds to support innovation are factors which are likely to influence the development of new inclusive programs and models.

In addition to the factors identified by Fullan (2001), Lieber and colleagues (2000) identified six key influences that assisted and sometimes challenged 16 programs in several states in the initiation and implementation of inclusive preschool programs. These six factors were (1) personnel who influence the program; (2) stakeholders involved with the program who share a common vision or concept of inclusion; (3) policies established by federal, state, and local agencies that influence inclusion; (4) training and external support for individuals associated with the program; (5) organizational structure development within the program that supports inclusion; and (6) the impact of individuals, groups, or agencies outside of the program that support the efforts for inclusion (Lieber et al.). Leiber and colleagues studied how these programs (which were located in multiple states) were able to begin inclusive programs for young children, and at what point key influences impacted the initiation and implementation of the programs.

Considering the sociopolitical environment of school, Brotherson, Sheriff, Milburn, and Schertz (2001) identified other barriers and facilitators to providing inclusive early childhood education. Obstacles included (a) an increase in the number of challenging children, (b) limited qualified personnel, and (c) incompatible regulations across programs. Factors that facilitated inclusion involved (a) early support for families, (b) strong community collaboration, and (c) key administrative officials providing supports for such programs. Further, in an analysis performed by Buysse, Wesley, and Keyes (1998), the development and implementation of early childhood inclusive programs also were influenced by the teacher-child ratio in classrooms, adequacy of 
classroom facilities, quality of child care, and time spent planning and coordinating special services to ensure the most effective educational and inclusive experiences for the children involved.

In summary, researchers examined: (a) the positive outcomes for young children with disabilities in inclusive settings; (b) the process of innovative educational change; (c) key influences in the initiation and continuation of inclusion; and (d) specific barriers to, and facilitators of, the initiation and continuation of inclusion.

To further influence the establishment and continuation of inclusive services, Guralnick (2000) suggests two central goals for consideration, "(1) achieving universal access to inclusive programs and (2) agreeing on and establishing feasible programs" (p. 214). This article focuses primarily on Guralnick's second goal to illustrate the processes whereby preschool inclusion programs were initiated and implemented in school districts and special education cooperatives within a single state. The two research questions that guided this qualitative study were (1) What factors impact the initiation of preschool inclusion services? and (2) What elements have local programs put into place to effect continuation of preschool inclusion? This study replicates and extends Lieber et al. (2000) by examining the themes they put forth, as well as developing new themes in the initiation and continuation of preschool inclusion programs.

The investigation used an extensive interview process to study how preschool programs addressed a variety of challenges to provide inclusion. The use of a qualitative, multiple embedded-case study design allowed a purposeful selection of sites for use in the study which enabled identification of sites having particularly unique characteristics. This design supported the collection of multiple sources of data related to the goals of the study, examination of a complex process (with many related components), and the development of informative case-descriptive reports to highlight and examine some of the unique challenges that these sites overcame to initiate and continue their inclusive programs.

\section{METHODS}

\section{SETTINGS AND PARTICIPANTS}

This study was conducted with five preschool programs located in a Midwestern state. Each of these programs had services for children with and without disabilities participating in all activities. The programs, however, were not homogeneous; they differed on one or more variables, including funding, design, and supervisory agent (see Table 1).

The purposeful sampling procedure for the study ensured that programs were deliberately selected for inclusion on the basis of criteria that addressed the research questions (Berg, 2001; Bogdan \& Biklen, 1998; Braud \& Anderson, 1998; Creswell, 1998; Patton, 2002). Request for participation in the present study began with identifying school districts and special education cooperatives that were implementing inclusive preschool services. Possible sites were drawn from across the selected state and included rural, urban, and suburban communities; sites served small to large populations, involved a variety of funding sources for services, and were viewed by state administrators as environments where effective practices were employed. The decision to invite a site to participate was also influenced by the researchers' goal: to study programs that had to address a range of challenges in implementing and maintaining inclusive preschool education. Table 1 (December 1 child count, 2002) presents some of the unique challenges the participating sites had to overcome or learn to work with to provide preschool inclusion.

With these criteria in place, the researchers first examined state Department of Education data on school districts and special education cooperatives to determine a set of potential sites according to basic information (location, population served, etc.). The researchers then requested assistance from the state Inservice Training System (ITS) and state Department of Education (SDE) to identify inclusive programs that met the specified criteria. In selecting a possible participation site, the study placed additional significance on programs that exhibited unique characteristics in developing and implementing inclusion programs, such as particular geographical challenges, relationships with a local univer- 


\begin{tabular}{|c|c|c|c|c|c|c|}
\hline Site & Location & $\begin{array}{l}\text { Special Education } \\
\text { Sponsoring Agency }\end{array}$ & & $\begin{array}{l}\text { Other Sponsoring } \\
\text { Agencies and } \\
\text { Funding Sources }\end{array}$ & $\begin{array}{l}\text { Number } \\
\text { of Children } \\
\text { Served }^{a}\end{array}$ & $\begin{array}{c}\text { Unique Site } \\
\text { Characteristics }\end{array}$ \\
\hline A & Rural & $\begin{array}{l}\text { Special education } \\
\text { cooperative }\end{array}$ & & $\begin{array}{l}\text { 4-Year-Old At-Risk } \\
\text { Head Start (school } \\
\text { district grantee) } \\
\text { Migrant Even Start }\end{array}$ & Medium & $\begin{array}{l}\text { - Geography is very rural, lies } \\
\text { within } 2 \text { time zones, and } \\
\text { encompasses } 20 \text { school } \\
\text { districts within } 12 \text { counties } \\
\text { - Variety of available options in } \\
\text { which children participated } \\
\text { - Teaming of the faculty, staff, } \\
\text { and administration } \\
\text { - Key individuals involved with } \\
\text { the program } \\
\text { - Willing to be adventurous }\end{array}$ \\
\hline B & $\begin{array}{l}\text { Urban/ } \\
\text { Suburban }\end{array}$ & $\begin{array}{l}\text { Public school } \\
\text { district }\end{array}$ & & $\begin{array}{l}\text { Community child } \\
\text { care/preschool } \\
\text { programs } \\
\text { 4-Year-Old At-Risk } \\
\text { Head Start (school } \\
\text { district grantee) }\end{array}$ & Medium & $\begin{array}{l}\text { - Strong level of collaboration } \\
\text { between local university and } \\
\text { the public school program } \\
\text { - Strong level of collaboration } \\
\text { between the community and } \\
\text { the public school program } \\
\text { - Incentives for faculty and } \\
\text { staff participation }\end{array}$ \\
\hline C & Rural & $\begin{array}{l}\text { Public school } \\
\text { district }\end{array}$ & & $\begin{array}{l}\text { Head Start (Early } \\
\text { Childhood Center } \\
\text { grantee) } \\
\text { Special education } \\
\text { cooperative } \\
\text { Indian Reservation }\end{array}$ & Small & $\begin{array}{l}\text { - Key individuals involved with } \\
\text { the program } \\
\text { - Community very involved } \\
\text { and influential }\end{array}$ \\
\hline D & $\begin{array}{l}\text { Urban/ } \\
\text { Suburban }\end{array}$ & $\begin{array}{l}\text { Special education } \\
\text { cooperative }\end{array}$ & - & $\begin{array}{l}\text { Head Start (school } \\
\text { district grantee) }\end{array}$ & Large & $\begin{array}{l}\text { - Personnel are well prepared } \\
\text { for program and highly } \\
\text { involved in decision-making } \\
\text { processes } \\
\text { - Program has high level of } \\
\text { support for children and } \\
\text { families } \\
\text { - Strong level of interagency } \\
\text { collaboration }\end{array}$ \\
\hline E & Rural & $\begin{array}{l}\text { Public school } \\
\text { district contract } \\
\text { to community } \\
\text { agency }\end{array}$ & - & $\begin{array}{l}\text { Head Start } \\
\text { (Community } \\
\text { Connections } \\
\text { grantee) } \\
\text { 4-Year-Old } \\
\text { At-Risk }\end{array}$ & Small & $\begin{array}{l}\text { Blended funding of multiple } \\
\text { sources to provided services } \\
\text { - Strong level of interagency } \\
\text { collaboration } \\
\text { - Program has high level of } \\
\text { support for children and } \\
\text { families }\end{array}$ \\
\hline
\end{tabular}

${ }^{\text {aSmall }}=0-75$ students; Medium $=76-150$ students; Large $=151-225$ students. 
sity, and collaboration with community agencies (see Table 1 for information about each site).

\section{DATA COLLECTION: INTERVIEWS OF KEY INFORMANTS}

Once districts or cooperatives agreed to participate, a primary key informant was contacted for further discussion on selection of interview participants (Creswell, 1998; Patton, 2002; Seidman, 1998). The primary key informants recommended and obtained consent for additional individuals to participate in the interview process (see Table 2 for specific interview and focus group participants by site). These key informants were current and former district or cooperative staff who had been actively involved in the initiation and continuation of inclusion for children with special needs programs. For the most part, the key informat ts were administrators and had little difficulty iclentifying other eligible participants.

Primarily one-on-one interviews were conducted with participants but, when necessary or appropriate, group interviews were employed (Bogdan \& Biklen, 1998; Creswell, 1998; Krueger \& Casey, 2000). The interviews were semistructured, guided by the overall research questions of the two studies (Merton \& Kendall, 1946, as cited in Bogdan \& Biklen). This enabled the study's first author to shape the interview according to systematic themes, but still allowed participants to tell their stories and for the researcher to probe beyond the standardized questions and answers (Berg, 2001; Bogdan \& Biklen; Marshall \& Rossman, 1999).

\section{DATA ANALYSIS AND CASE WRITING}

Interviews were the primary data collection source, therefore the primary data analysis source was the interview transcripts. The analysis technique consisted of the coding of participants' statementsextracted from nearly 300 pages of written transcripts. The researchers used quotations from the interview transcripts and the notes that were made during the interview to identify key terms and phrases that captured the respondents' language and views of the program (Marshall \& Rossman, 1999; Patton, 2002). For the present study, the researchers identified "substantive statements" (Gillham, 2000) or pieces of information that represented data aligned with the research questions within each transcript. These statements then were coded according to predetermined "key influences" (Lieber et al., 2000) and using additional categories that emerged in the analysis and which were specific to the research questions (Table 3).

After all of the transcripts for a case were fully analyzed, the first author summarized all substantive statements under each coded category. A matrix was developed to visually display each respondent's substantive statements according to the categories of the analyzed data. This type of visual display "brings the summary category to life" and "conveys the range of responses that come under it" (Gillham, 2000, p. 75). In addition, vignettes, quotes, timelines, and visual figures or charts were used to assist in understanding each program.

Using all of the information collected, a casestudy method was employed for the full reporting of the study. The development of descriptive case reports for each participating site facilitates the use of multiple sources for data collection (Bogdan \& Biklen, 1998; Braud \& Anderson, 1998; Yin, 2002), with interviewing being the primary source (Bogdan \& Biklen; Creswell, 1998; Patton, 2002; Seidman, 1998). Observation, document analysis, and other forms of data collection were employed, however, because these data led the researchers to additional sources of information (Bogdan \& Biklen).

The authors employed triangulation, peer review/debriefing, and member checking to ensure the accuracy and trustworthiness of the data and the case studies. In the data-collection process, triangulation was achieved through the use of multiple methods including interviews, focus groups, and document review (Patton, 2002; Stake, 1995). The authors employed peer review and debriefing through the use of a committee of university faculty and State Department of Education/Inservice Training System staff. Key informants (as previously described) were requested to participate in the study and assist with the identification of interview participants. These individuals - who were considered program experts - also assisted with review of data analysis and case development. 


\begin{tabular}{cccc}
\hline Interviewee and & Interview & \\
Site & Focus Group Role/Position & (min) & Interview Location \\
& &
\end{tabular}

A Former Cooperative Director

Cooperative Early Childhood Special Education Teacher \#1

60

Cooperative Early Childhood Special Education Teachers $(n=8)$ not included in other interviews

Administrators Focus Group:

Current Director and two administrators

Additional focus group:

Cooperative Early Childhood Special Education Teacher

Cooperative Early Childhood Special Education Paraeducator

Director of Special Education

Early Childhood Special Education Teacher \#1

Early Childhood Special Education Teacher \#2

University Faculty \#1

University Faculty \#2

C Former superintendent of school district

Indian Nation Reservation Early Childhood Education

Center Early Childhood Special Education Teacher

Indian Nation Reservation Early Childhood Education

Center Director

D Cooperative Administrator

Community Programs/Head Start Administrator

Community Programs Coordinator;

Former Head Start Teacher

Cooperative Early Childhood Special Education Teacher \#1

Cooperative Early Childhood Special Education Teacher \#2

Cooperative School Psychologist

Head Start Teacher

Cooperative Speech/Language Pathologist

E Director of Special Education

Early Childhood Special Education Administrator

Early Childhood Special Education Teacher
60

60

20

State Department of Education

Elementary school

Early Learning Center

Cooperative main office

45 Cooperative main office

60 Grade school

45 District office

60 Special Education Department

District office

60 University

60 University

60 University

60 University

45 Early Childhood Education Center

30 Early Childhood Education Center

$30 \quad$ Middle school

$30 \quad$ Programs Building

45 Programs Building

$30 \quad$ Programs Building

45 Programs Building

45 Programs Building

$30 \quad$ Programs Building

$30 \quad$ Programs Building

45 High school

75 Community agency office

30 Via telephone
For member checking, one or two key informants from each participating site were asked to review the data-analysis procedures as well as the assertions, and to draft the case report prior to completion of the study (Stake, 1995). The case report was sent electronically from researcher $\mathrm{M}$. L. Purcell to the site contact. Upon completion of review, the contact performing the member check at the site either sent approval for the report and expressed agreement with the findings, or the contact and Purcell worked together to re-examine points of disagreement to come to a consensus on the assertions of the case. Through follow-up contacts the report then was reviewed using this same procedure until full agreement was attained.

\section{RESULTS}

The substantive statements identified in the transcripts were coded using the previously developed 


\begin{tabular}{ll}
\hline Key Factor & \multicolumn{1}{c}{ Definition } \\
\hline $\begin{array}{l}\text { Collaborative } \\
\text { Relationships }\end{array}$ & $\begin{array}{l}\text { The formal and informal relationships between agencies to work together in the provision of } \\
\text { inclusive services. Examples of these relationships include formal contracts for funds and } \\
\text { services, regularly scheduled meetings, and informal conversations to ensure the success of the } \\
\text { program. }\end{array}$
\end{tabular}

Community Influence ${ }^{\mathrm{a}}$

Family

Key Personnel ${ }^{\mathrm{a}}$

Organizational

Structure ${ }^{a}$

National, State Local Policies and How They Are Enacted $^{a}$

Shared Vision ${ }^{\mathrm{a}}$

Training and External Support ${ }^{\mathrm{a}}$

Influence exerted by community members (e.g., families) who are not employees of the school district or other agencies such as Head Start.

Family as Initiator (initiation): The initial influence exerted by one or more families of children with disabilities on inclusive practices in the early childhood special education program. Family Support and Partnership (maintenance): The support, training, or participation opportunities for parents of children involved with the inclusive program.

The influence of a specific person or people employed by the program on inclusive practices in the program. Influence can be ongoing, can be sparked by an event (hearing a presentation), can be sparked by previous experience, or can wane (e.g., a charismatic leader whose interests turn to a new innovation).

Structures that exist within a district and between different agencies so that people can communicate, collaborate, and share resources. This includes formal interagency agreements.

Policies established by national agencies (Head Start or OSEP) or state agencies that influence practices that occur in local programs. Examples of these influences are the LRE provisions from Pub. L. No. 94-142, the Head Start "10\%" mandate for children with disabilities, and state or regional level administrators' enactment or enforcement of policies at the classroom level.

The transformation of the concept of inclusion that occurs over time among those who design, deliver, or use inclusive education, so that it includes the views of all participants.

Any money, training, other type of support, or special recognition beyond regular program money or support that is associated with the startup of a program.

${ }^{a}$ Adapted (with permission) from J. Lieber et al. (2000), Key Influences on the Initiation and Implementation of Inclusive Preschool Programs, Exceptional Children, 67, p. 83.

key influences from Lieber et al. (2000) and two additional factors-collaborative relationship and family as initiator/family support and partnership that emerged during the data analysis process (see Table 3 for a listing of all eight key factors). As noted, individual case reports were developed for each site. Drawing from these case studies, this article reports data pertinent to each site, with the goal of providing cross-site analyses for a diverse group of programs.

Based upon peer analysis of the transcript data, the key factors that emerged were sorted into four categories: (1) supporting initiation, (2) supporting continuation, (3) challenging initiation, and (4) challenging continuation of preschool programs. Table 4 shows which sites reported key factors that most impacted their pro- gram initiation and continuation. Only the key factors that are primary in the initiation and continuation of inclusion are included in Table 4. Thus, if a key factor was not included in the table, it might have been mentioned by interview participants, but it was not identified as a primary factor in the sites' data on initiation or continuation of the program. Primary factors were those that appeared most often in the coded transcripts.

\section{KEY FACTORS SUPPORTING INITIATION}

Key personnel and shared vision were the overwhelmingly predominant supporting factors in initiation of inclusive programs. Regarding key personnel, many interview participants referred to individuals who "made it happen" or set things in motion for a transition to inclusion or, as in the 
Sites Reporting Key Factors as Primary in Supporting or Challenging Inclusion

\begin{tabular}{lllll}
\hline Key Factor & $\begin{array}{c}\text { Primary Factors } \\
\text { Supporting } \\
\text { Initiation }\end{array}$ & $\begin{array}{c}\text { Primary Factors } \\
\text { Supporting } \\
\text { Continuation }\end{array}$ & $\begin{array}{c}\text { Primary Factors } \\
\text { Challenging } \\
\text { Initiation }\end{array}$ & $\begin{array}{c}\text { Primary Factors } \\
\text { Challenging } \\
\text { Continuation }\end{array}$ \\
\hline $\begin{array}{l}\text { Collaborative Relationship } \\
\text { Community Influence }\end{array}$ & Sites: B, D & Sites: B, C, D & Sites: A, B & Sites: A, C, D \\
$\begin{array}{l}\text { Family Support \& } \\
\text { Partnership }\end{array}$ & - & - & Site: A & Sites: A, E \\
$\begin{array}{l}\text { Key Personnel } \\
\text { Organizational Structure }\end{array}$ & Sites: A, B, C, D & - & - & - \\
$\begin{array}{l}\text { Policy } \\
\text { Shared Vision }\end{array}$ & Sites: A, B & Site: C & Site: C & - \\
Training \& External & Sites: A, C, D, E & Sites: A, C, D & Sites: A, B, C, D, E & Sites: A, B \\
Support & Site: D & Sites: A, B, E & - & Sites: B, C, D \\
\hline
\end{tabular}

case of Site A, to even begin early childhood special education services. Typically, these agents of change were administrative staff from school districts, educational cooperatives, and Head Start programs. Participants from Site A, for example, indicated that the lead change agent was the former cooperative director. It was reported that the director had worked predominantly with the early childhood special education and school district staff to establish classrooms and playgroups, she could find no programs in some communities with which to partner and thus found no options for inclusive services. For Site B, the primary change agents came from the local university. Key individuals in this case historically brought state and federal grants into the district to provide inclusion for the preschool, and to prepare staff and community programs for inclusion. Families were not mentioned in interviews as the primary change agents. This could be because only school district personnel were nominated by key informants and were available for interviews at each site.

Key personnel and shared vision were the overwhelmingly predominant supporting factors in initiation of inclusive programs.

Shared vision also was a predominant factor in supporting initiation of preschool inclusion.
Most people in the sites agreed that inclusion is the most appropriate model for the education of all children. Several of the sites were transforming from traditional programs of early childhood special education to programs of inclusion, and the change was not always easy. Nevertheless, there was positive support for such programs, as illustrated by the administrative and teaching staff at Site D who indicated that inclusion was "what is best for kids" and this was the driving force to support their change. "The main thing is children. The difference of the disability is such a small part of being a child. . . . It would be really something [for it to be] more about the child than disability" (Former Cooperative Director).

\section{KEY FACTORS SUPPORTING CONTINUATION}

Organizational structure was the predominant supporting factor in continuing inclusive models. Once programs began, they built the structure to support continuance. Four of the programs relied on this for their continuation. Site A, for example, used a teaming structure to support the early childhood special education teachers. As shown in Table 1, Site A had a vast geographic range to supervise. The teachers reported that they easily could have felt very isolated and "on their own." The cooperative, however, established and supported teaming activities among the early childhood special education staff to collaborate, mentor, and observe each other in practice. These 
opportunities gave the teachers the time to problem solve and also provided support as teachers encountered a variety of challenges.

$[\mathrm{W}] \mathrm{e}$ do have meetings once a month and we do get together, and that motivation comes from each other, kind of patting each other on the back. We spend a lot of time with concerns: "How would you handle this situation?" (Early Childhood Special Education Teacher)

As preschool inclusion was being implemented in Site B, the school district developed relationships with community preschool programs. To continue these relationships, "barter style" agreements evolved. For example, if a child was receiving services at a community-based program rather than paying directly for tuition, then the school district provided materials and supplies, staff salaries, or paraeducator support. Similarly, Site D established contracts among all partnering organizations. These contracts were reviewed regularly, especially when program policies (such as Head Start or IDEA regulations) changed.

Children are currently enrolled in just about every place you can find a child. We have children at home, we have children at preschools, childcare centers, home daycares, the 4-Year-Old At-Risk program. . . . We're also trying to do playgroups. (Early Childhood Special Education Teacher)

Beyond the formal contracts, Site D also had informal mentoring and partnering agreements with Head Start and early childhood special education teaching staff. This included Head Start and early childhood special education teachers coordinating and collaborating to complete the paperwork necessary for each program and to ensure accountability to regulations. "I think actually the day-to-day motivation comes from my peers and co-workers, my team. . . . I love coming to work, love my team, love my job" (Head Start Teacher).

\section{KEY FACTORS CHALLENGING INITIATION}

Although it was identified as a supporting factor, interview participants in all sites identified shared vision as a challenge to initiating inclusive models. All sites reported the lack of a common goal or vision for inclusion as a major challenge in starting inclusive programs. At Site E, for example, participants identified concerns about their own effectiveness and ability to teach in an inclusive setting. Additionally, families of children with disabilities voiced concern about the quality of services. Not only were they concerned that their children with special needs might not receive the direct intensity of service desired but also, for 1 site that partnered with Head Start and 4-Year-Old At-Risk programs, various families initially expressed concern about their particular child with a disability being in a classroom with children from low-income families.

For parents, there was some resistance from the special education side . . . their first feeling was that services would be watered down ... some of our Head Start staff weren't too certain they could work with children with more severe needs. They didn't have confidence in themselves. (District Administrator)

When partnering with community programs, such as in Site A, Site B, and Site C, the varieties of programs proved challenging for collaboration due to different perspectives about curricula for educating young children. Particularly for Site A and Site B, itinerant early childhood special education teachers were working with multiple community programs and had to learn to adapt to each perspective of education and inclusion.

\section{KEY FACTORS CHALLENGING CONTINUATION}

Collaborative relationships and policy are identified as challenges to the continuation of inclusive programs in most of the participating sites. Frequently discussed by the respondents was the challenge of continuing collaboration among teachers, administration, and various partners as personnel changed and expectations for the education of young children increased. Also, some participants indicated that working with community programs which had a high staff-turnover rate and fewer well-trained staff members was a great challenge. Early childhood special education teachers and administrators indicated that they "started over" many times with training and support to ensure effective educational and inclusive experiences for the children with special needs in these settings. 
She [community preschool teacher] is the teacher. She doesn't have any educational training. It's just "Well, I think I want to do this." But as far as really knowing a scope and sequence of how children learn, she doesn't. . . . If they think you are judging them ... you are not going to make any progress." (Early Childhood Special Education Itinerant Teacher)

Many of the sites were early childhood special education and Head Start partnerships, therefore federal policy changes frequently were mentioned as a challenge. When a federal program - such as Head Start-changed regulations, the district or cooperative would work to adapt the preschool program regulations just in time for regulations of another federal program-such as IDEA-to change. Data for Site E, in particular, indicated the difficulty of constant alterations to the way funding agreements were developed to ensure compliance with ever-changing regulations.

\section{DISCUSSION}

The purpose of this study was to understand, describe, and expand the literature regarding how school districts and special education cooperatives initiated and continued preschool inclusive programs. The Midwestern state in this study provided opportunities for investigation of small, large, rural, and urban school districts-including special education cooperatives-while employing the same statewide systems of finance and techni$\mathrm{cal}$ assistance. This allowed the researchers to study challenges and facilitators to inclusive education when factors involving funding and available assistance were generally similar.

\section{Collaborative relationships and policy are identified as challenges to the continuation of inclusive programs.}

When comparing the results of the present study to prior investigations, the researchers replicated some of the previous findings but also expanded upon them. Overall, the findings were consistent with those of Odom, Horn et al. (1999), as well as with past research on the pro- cesses involved in educational change (Fullan, 2001; Mayrowetz \& Weinstein, 1999; Peck et al., 1993; Wesley \& Buysse, 1996). The barriers and facilitators identified in the current study also were onsistent with those cited in earlier studies (e.g., Bricker, 2000; Leiber et al., 2000; Odom, Hanson et al., 2001). This study, however, revealed some remarkable challenges that the participating sites continually had to overcome to ensure an effective and beneficial educational experience for all young children, including those with disabilities. This extends the understanding of what is needed to initiate and continue inclusive services for young children with disabilities.

\section{KEY FACTORS FOR CHANGE}

One way that the present study extends the analysis of Lieber et al. (2000) is through the identification of two additional themes from the discussions by the informants (all eight key factors are defined in Table 3). These two additional themes were: collaborative relationship and family as initiatorlfamily support and partnership. Seven of these eight key factors were identified as facilitators and barriers to initiation or continuation of preschool inclusion. Family support and partnership was identified as a facilitator in continuation in only one site (as shown in Table 4). The following discussion (aligned with Table 4) highlights the present study's identification of predominant key factors in initiation and continuation of preschool inclusion.

Initiation. As revealed in cross-site analysis highlighted in Table 4, key personnel and shared vision overwhelmingly were identified as the facilitators of initiation of inclusive services in the research sites. Many of the interview participants within and across sites agreed that inclusion was the preferred model for providing services for young children with disabilities.

Of the four sites that identified a key individual as the person who initiated the movement toward inclusion, three identified a special education administrator, Head Start administrator, or school district superintendent as the individuals that were key agents of change in initiating an inclusive model. The sources at the fourth site (at the time of initiation) reported hav- 
ing a very collaborative relationship with the local university. A university faculty member was identified as the advocate for initiating inclusion at that site.

Although shared vision was reported as a facilitator, surprisingly it also was reported by all five sites as a challenge to initiation. The interview participants reported the lack of a shared vision across sites as a problem. Interview participants identified situations in initiation where some individuals or groups of teaching or administrative staff within or across agencies disagreed initially with the move to inclusion but, over time, recognized the benefits of the model. Within the primary group that initiated the move to inclusion (i.e., special education teachers and administrators), all were in agreement on the vision of providing inclusion as the preferred model for service. To establish inclusive programs in all sites, however, special education staff had to collaborate with multiple individuals and organizations-parties which might or might not have shared their vision of inclusion. Interview participants also reported that families of children with disabilities initially expressed concerns that a move to inclusion would have a negative impact on the quality of the program, and that their children would not receive an education tailored to their individual needs.

Families were not identified as initiators of inclusion in any of the sites. This contrasts with previous studies. Soodak and Erwin (2000), for example, reported that families of young children with disabilities often must work very hard to create (or initiate) effective inclusive programs for their children. It is possible that families as initiators was not identified as a primary factor in any of the current sites because the informants included only educators and administrators. It is possible that, at these sites, the parents of current or former students with disabilities could have provided a more expanded version of who initiated inclusive services.

Continuation. The identification of facilitators for continuation of inclusion was relatively balanced across the five sites and four of the eight key factors, as highlighted in Table 4. Three of the sites reported collaborative relationships, shared vision, and training and external support as factors that supported them in continuing to provide in- clusive programs. Four sites identified organizational structure as a facilitator for continuation.

Under ideas of these three key factors, varieties of strategies emerged. Participants reported that systems within the organizations that developed over time and supported the continuation of inclusion, for example, were (a) mentoring and teaming among the teachers, (b) early childhood special education teachers working with the team of general early childhood teachers, and (c) early childhood special education teachers serving not only as head classroom teachers but also as itinerant teachers for the general early childhood classrooms.

Additionally, social supports for the staff were an important ingredient in continuing inclusive services. Staff members in three of the sites reported that they spent time getting to know one another as people and not just as professionals. The interview participants indicated that they were able to maintain effective inclusive programs because they had the opportunity to get to know - and learn to respect-one another.

Last, providing inclusive preschool programs involved formal and informal agreements among organizations such as an LEA, community childcare services, and preschool programs. Because most of the sites did not have LEA sponsored "traditional" preschools, the special education sponsoring agency for each research site collaborated with at least one other agency or funding stream to provide inclusive opportunities. Collaboration among agencies or grantees was very important and, without these collaborations, many of these sites would not have been able to provide inclusive services.

This feature of the present study is very much in alignment with the findings of Odom, Horn and colleagues (1999), who identified a variety of organizational contexts where children with disabilities are enrolled, including (a) preschool and child-care programs that are not associated with the school district or special education cooperative in the research site, (b) Head Start classrooms, and (c) preschool classrooms operated by the school district. Likewise, the children with disabilities who were located in the current research sites had their individualized services provided through a variety of different educational arrangements including (a) an early 
childhood special education teacher or related service personnel providing itinerant services at the inclusive site; (b) early childhood special education teachers collaborating, consulting, and team teaching with general early childhood educators in the inclusive classrooms; and (c) early childhood special education teachers leading inclusive classrooms.

The area which had the fewest factors reported as challenges was continuation (see Table 4). Regarding policy, interview participants at three sites made reference to constantly changing policies and having to stay informed about changes. These sites had multiple collaborative partners or funding streams, so there also were multiple sets of policies that participants had to know-such as IDEA, Head Start, and 4-Year-Old At-Risk legislation and regulations. These constant changes also affected collaborative relationships among the partners within the different sites. An interview participant in one site stated that it was difficult for the collaborating agencies to remain informed of the changes in each other's funding source policies. This lack of awareness of policy change can cause friction between the agencies when funding emergencies arise. Staff turnover in LEAs and community programs also was a constant challenge, particularly when individuals enter the inclusive model and might not be informed of-or in agreement with - aspects such as the vision or organizational structures that have been established.

\section{LIMITATIONS OF THE PRESENT ST U D Y}

Several limitations must be taken into account when considering the findings from the present study. Although the sample size included five research sites with multiple numbers of interviews and focus group participants in each site, this was by no means an exhaustive group from which large-scale judgments or generalizations can be made.

A second limitation involves the key informants in the sites. There was one person at each site with which the first author communicated regarding identification of interview participants and particular programs within a site. All five of the primary key informants were employees of the
LEA or a collaborative agency, and this could have resulted in a bias in terms of the selection of persons to interview. Other important voices therefore might not have been included; for example, no parents were involved in the interviews. Although parent opinions were requested, key informants made no recommendations for parent participation in the research process. Thus, the results of this study are limited to a professional perspective.

\section{CONCLUSION}

This study was designed to examine how five school districts and special education cooperatives in a Midwestern state initiated and continued inclusive service models for their preschool students with disabilities. Although there is evidence that inclusion has a positive impact on children with disabilities (e.g., Guralnick, 2001; Leyser \& Kirk, 2004; Stahmer \& Carter, 2005), issues surrounding how best to deliver inclusive services still remain unresolved (Guralnick, 2000), and include, "How can we establish inclusive preschool programs?" and "How do we make inclusive preschool programs accessible to all young children with disabilities?" The stories of participants at these research sites identified strengths and challenges to providing effective inclusive service models for the majority of their preschool students with disabilities. Through these stories, previously identified key factors for the initiation and continuation of inclusion were addressed and new influences emerged.

An especially important theme was collaborative relationships. Interview participants in all sites report collaborating with other individuals, groups, and agencies to provide inclusive service models for young children with disabilities. The following quote from one interview participant highlights this recurrent theme of collaboration as an important feature of a successful inclusive program.

Because children are our future and they deserve the best ... if we can convince everybody that we are all working for the same goal that all of our children are worth the effort to do this because they are going to bring us into the future and we need to take 
care of their needs now [i]t's worth every effort. Whatever the challenges are, we can work through them if we all work together. (Center Director)

\section{MPLICATIONS}

This study examined the initiation and continuation of preschool inclusion programs. The facilitators and challenges identified in this study provide LEAs and teachers with possible solutions which they should consider in developing and maintaining their own inclusive programs. The sample of sites for the current study was chosen to represent small, large, rural, and urban sites. Further, the use of both individual school districts and special education cooperatives adds an additional contextual factor. There was a variety of unique issues associated with developing and continuing preschool inclusive programs in these sites. Other LEAs are encouraged to consider whether these are pertinent to their own situations, and to use this information to help develop new programs or to improve existing inclusive programs.

Some general areas to address when considering initiating or continuing an inclusive model are (a) utilizing key personnel, (b) having a shared vision, (c) employing a strong training and support model for staff, and (d) ensuring strong collaborative relationships. These areas are applicable to student of all ages.

When planning or continuing an inclusive model, LEAs should look to key individuals (predominantly administrators, as revealed in the current study) to support the initiative from the beginning of the program and throughout its life. Possessing a shared vision also is essential to supporting the development and continuation of an inclusive model. Over time, it also is critical to have a variety of training and support opportunities for the teaching and related service staff, so that everyone involved has the needed skills and so these skills can be further upgraded. Many LEAs do not have their own preschool programs for children who are developing typically, therefore LEAs often must collaborate with other organizations. Developing a strong collaborative partnership supports the initiation and continua- tion of an inclusive program. LEAs and partner agencies should establish written policy regarding financial and managerial responsibility. Clearly identifying which agency (or funding source) is responsible for the variety of instructional and noninstructional costs, hiring, and supervision of staff assists a program in continuing its endeavor.

\section{FUTURE RESEARCH}

The qualitative study of process and perceptions (such as that done in the present study) provides important information, but there remains a need to collect outcome data on the impact of inclusion. For example, it would be useful to compare the effectiveness of different options (such as those identified in this study) on the programs of preschool children with and without disabilities.

An additional area for further research involves examining issues surrounding funding. For example, one participant questioned the blending of funds for classrooms specifically for groups that have state or federal assistance programs (i.e., special education for students with disabilities, Head Start, and 4-Year-Old At-Risk for children in families with low socioeconomic status) to provide inclusive opportunities. The interviewee expressed concern that the blending of these funding sources and programs could still be considered segregation because classrooms were organized around specific groups of children rather than all children. Not only should future research examine such perceptions and attitudes more fully, but it also would be helpful to examine the effectiveness of programs that provide a classwithin-a-class for students with disabilities.

\section{REFERENCES}

Berg, B. L. (2001). Qualitative research methods for the social sciences. Boston: Allyn \& Bacon.

Bogdan, R. C., \& Biklen, S. K. (1998). Qualitative research for education: An introduction to theory and methods (3rd ed.). Boston: Allyn \& Bacon.

Braud, W., \& Anderson, R. (1998). Transpersonal research methods for the social sciences: Honoring human experience. Thousand Oaks: Sage. 
Bricker, D. (2000). Inclusion: How the scene has changed. Topics in Early Childhood Special Education, 20, 14-19.

Brotherson, M., Sheriff, G., Milburn, P., \& Schertz, M. (2001). Elementary school principals and their needs and issues for inclusive early childhood programs. Topics in Early Childhood Special Education, 21, 31-45.

Buysse, V., \& Bailey, D. B. (1993). Behavioral and developmental outcomes in young children with disabilities in integrated and segregated settings: A review of comparative studies. The Journal of Special Education, 26, $434-461$.

Buysse, V., Wesley, P., Bryant, D., \& Gardner, D. (1999). Quality of early childhood programs in inclusive and noninclusive settings. Exceptional Children, 65, 301-314.

Buysse, V., Wesley, P., \& Keyes, L. (1998). Implementing early childhood inclusion: Barrier and support factors. Early Childhood Research Quarterly, 13, 169-184.

Creswell, J. W. (1998). Qualitative inquiry and research design: Choosing among five traditions. Thousand Oaks: Sage.

December 1 child count. (2002). Kansas Inservice Training System Newsletter, 11, 2-5.

File, N., \& Kontos, S. (1992). Indirect service delivery through consultation: Review and implications for early intervention. Journal of Early Intervention, 16, 221-233.

Fullan, M. (2001). The new meaning of educational change (3rd ed.). New York: Teachers College Press.

Gillham, B. (2000). Case study research methods. New York: Continuum.

Guralnick, M. J. (2000). An agenda for change in early childhood inclusion. Journal of Early Intervention, 23, 213-222.

Guralnick, M. J. (2001). A framework for change in early childhood education. In M.J. Guralnick (Ed.), Early childhood inclusion: Focus on change (pp. 3-38). Baltimore: Brookes.

Horn, E. M., Thompson, B., Palmer, S. B., Jenson, R., \& Turbiville, V. (2004). Preschool. In C. H. Kennedy \& E. M. Horn (Eds.), Including students with severe disabilities (pp. 207-221). Boston: Pearson Education.

Individuals With Disabilities Education Amendments of 1997, Pub. L. No. 105-17, 111 Stat. 37 (1997).

Individuals With Disabilities Education Improvement Act Amendments of 2004, Pub. L. No. 108-446, 118 Stat. 2647 (2004).
Krueger, R. A., \& Casey, M. (2000). Focus groups: A practical guide for applied research (3rd ed.). Thousand Oaks: Sage.

Lamorey, S., \& Bricker, D. D. (1993). Integrated programs: Effects on young children and their parents. In C. A. Peck, S. L. Odom, \& D. D. Bricker (Eds.), Integrating young children with disabilities into community programs: Ecological perspectives on research and implementation (pp. 249-270). Baltimore: Brookes.

Leyser, Y., \& Kirk, R. (2004). Evaluating inclusion: An examination of parent views and factors influencing their perspectives. International Journal of Disability, Development, and Education, 51, 271-285.

Lieber, J., Hanson, M., Beckman, P., Odom, S., Sandall, S., Schwartz, I., et al. (2000). Key influences on the initiation and implementation of inclusive preschool programs. Exceptional Children, 67, 83-98.

Marshall, C., \& Rossman, G.B. (1999). Designing qualitative research (3rd ed.). Thousand Oaks: Sage.

Mayrowetz, D., \& Weinstein, C. (1999). Sources of leadership for inclusive education: Creating schools for all children. Educational Administration Quarterly, 35, 423-449.

Nolet, V., \& McLaughlin, M. J. (2000). Accessing the general curriculum: Including students with disabilities in Standards-Based Reform. Thousand Oaks, CA: Corwin Press.

Odom, S. L., Hanson, M. J., Lieber, J., Marquart, J., Sandall, S., Wolery, R., et al. (2001). The costs of preschool inclusion. Topics in Early Childhood Special Education, 21, 46-55.

Odom, S. L., Horn, E. M., Marquart, J. M., Hanson, M. J., Wolfberg, P., Beckman, P., et al. (1999). On the forms of inclusion: Organizational context and individualized service models. Journal of Early Intervention, 22, 185-199.

Odom, S. L., Parrish, T. B., \& Hikido, C. (2001). The costs of inclusive and traditional special education preschool services. Journal of Special Education Leadership, 14, 33-41.

Odom, S. L., Wolery, R., Lieber, J., Sandall, S., Hanson, M. J., Beckman, P., et al. (1999). Preschool inclusion: A review from an ecological systems perspective. Unpublished manuscript.

Patton, M. Q. (2002). Qualitative research and evaluation methods (3rd ed.). Thousand Oaks: Sage.

Peck, C., Furman, G., \& Helmstetter, E. (1993). Integrated early childhood programs. In C. A. Peck, S. L. Odom, \& D. D. Bricker (Eds.), Integrating young children with disabilities into community programs: Ecologi- 
cal perspectives on research and implementation (pp. 187-206). Baltimore: Brookes.

Seidman, I. (1998). Interviewing as qualitative research: A guide for researchers in education and the social sciences (2nd ed.). New York: Teachers College Press.

Soodak, L. C., \& Erwin, E. J. (2000). Valued member or tolerated participant: Parents' experiences in inclusive early childhood settings. Journal of The Association for Persons with Severe Handicaps, 25, 29-41.

Stahmer, A., \& Carter, C. (2005). An empirical examination of toddler development in inclusive childcare. Early Child Development and Care, 175, 321-333.

Stake, R. E. (1995). The art of case study research. Thousand Oaks: Sage.

Wesley, P. W., \& Buysse, V. (1996). Supporting early childhood inclusion: Lessons learned through a statewide technical assistance project. Topics in Early Childhood Special Education, 16, 476-499.

Yin, R. K. (2002). Case study research: Design and methods (3rd ed.). Thousand Oaks: Sage.

\section{ABOUT THE AUTHORS}

MEGAN L. PURCELL (CEC KY Federation), Assistant Professor, Department of Special Education, Eastern Kentucky University, Richmond. EVA HORN (CEC KS Federation), Professor, Department of Special Education; and SusAN PALMER (CEC KS Federation), Associate Research Professor, Bureau of Child Research, University of Kansas, Lawrence.

Address correspondence to Megan L. Purcell, 245 Wallace Building, 521 Lancaster Avenue, Richmond, KY 40475 (e-mail: megan.purcell@ eku.edu).

Manuscript received November 11, 2006; accepted March 2007.

BASED ON THE \#1 BEST-SELLING PUBLICATION AT CEC'S ANNUAL CONVENTION

Two-Day Workshop

Response to Intervention:

A Practical Guide for Every Teacher

For educators who are new to the Response to Intervention (RTI) approach, this workshop is a practical guide for every teacher. It offers an overview of key concepts and guidelines of RTI that benefit students in inclusive classrooms. Cara Shores, co-author of Response to Intervention: A Practical Guide for Every Teacher, demonstrates how general and special education teachers can use research-based intervention to effectively individualize instruction, monitor student progress, and implement strategies to meet students' specific needs.

\section{Gain essential information that translates into practical tools and guidelines!}

\section{LEARNER OUTCOMES}

Participants will be able to:

- Identify the major components of two models of RTI.

- Identify resources for selection of research-based strategies and curriculum based measurement.

- Utilize the RTI process to identify learning problems based on student outcome data.

\section{TWO DAYS, TWO CITIES}

San Diego, CA and Washington, D.C.

For hotel information call 888-232-7733 or visit the CEC Web site at www.cec.sped.org

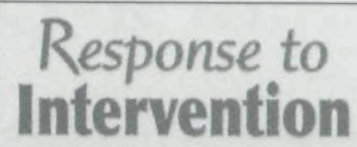

- A Practical Guide for Every Teacher -

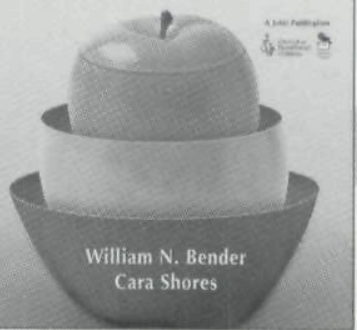

CEC extends its thanks to Corwin Press for supporting the 2007 RTI Regional Workshops 
Copyright of Exceptional Children is the property of Council for Exceptional Children and its content may not be copied or emailed to multiple sites or posted to a listserv without the copyright holder's express written permission. However, users may print, download, or email articles for individual use. 